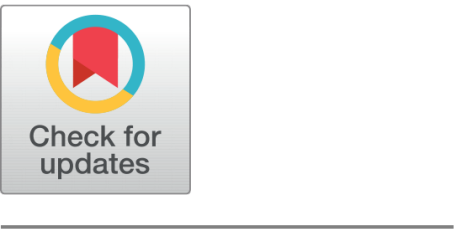

G OPEN ACCESS

Received: $12-02-2020$

Accepted: 15-03-2020

Published: 20-03-2020

Editor: Dr. Natarajan Gajendran

Citation: Tupas FP, Matsuura T (2020) Integrating arts in the basic science curriculum: in the context of local marine resources in the Visayan sea. Indian Journal of Science and Technology 13(11): 1248-1258. https://doi.org/ 10.17485/IJST/V13i11.149967_2020

*Corresponding author. Fernan Peniero Tupas

Northern Iloilo Polytechnic State College, Estancia, lloilo, Philippines

International Research Fellow, Japan Society for Promotion Science (JSPS),

Tokyo, Japan

Hokkaido University of Education, Hakodate, Hokkaido, Japan fernantupas@yahoo.com

Funding: Japan Society for the Promotion of Science (JSPS)

Competing Interests: None

Copyright: @ 2020 Tupas, Matsuura. This is an open access article distributed under the terms of the Creative Commons Attribution License, which permits unrestricted use, distribution, and reproduction in any medium, provided the original author and source are credited.

Published By Indian Society for Education and Environment (iSee)

\section{Integrating arts in the basic science curriculum: in the context of local marine resources in the Visayan sea}

\author{
Fernan Peniero Tupas ${ }^{1,2,3 *}$, Toshihiko Matsuura ${ }^{3}$ \\ 1 Northern Iloilo Polytechnic State College, Estancia, Iloilo, Philippines \\ 2 International Research Fellow, Japan Society for Promotion Science (JSPS), Tokyo, Japan \\ 3 Hokkaido University of Education, Hakodate, Hokkaido, Japan
}

\section{Abstract}

Purpose: The research aims to create visual aids from recycled materials in the context of marine resources in science pedagogy in the K 12 Basic Education Program in the Philippines. Methods: The researchers identified various local resources in the area and created visual aids. The purposively selected $21 \mathrm{sci}-$ ence experts in Northern lloilo evaluated the finished product using a checklist. They were interviewed and their feedback was analyzed. Determination of the lessons to which the visual aids can be integrated was done. The percentage in the checklist was determined, and visual aids were ranked based on the output. Findings/application: The most abundant marine resources in the area are mangrove, fishes, corals, and sea grasses because it is located within the vicinity of the Visayan Sea. The finished output were called 'Mangrovy Kind of Love', 'Fish Bowl', 'Corals: Bleaching No More', and 'Grasses on the Sea'. The four outputs were original but experts in marine resources were consulted to determine the exact parts and basic features of every organism. Also, the local, English and scientific names were included in the outputs. Based on the evaluations, the outputs have great potential as instructional materials in teaching science but need some improvement. The four identified local marine resources are part of the basic science curriculum. But, these creative outputs can be used specifically in grades $4,5,6$, and 8 . The experts also requested that the researchers will create instructional materials to see how these innovations will be incorporated into the science pedagogy. The comments and suggestions were incorporated to make the final outputs more interesting to the learners. 3.1 Thus, integrating arts in the STEM curriculum can help the current situation of the Philippine education system. Teachers must be imaginative to invent attention-grabbing materials to lift students' interest in science.

Keywords: Visual Aids; Basic Education; Science Curriculum; Visayan Sea; Marine Resources 


\section{Introduction}

'The oceans are connected to everyone, every place in the world. Mote's new Science Education Aquarium will ignite within each visitor a greater degree of curiosity to learn more about the marine environment and to protect it ${ }^{(1)}$.

Thus, the ocean is the most treasured asset in the entire planet. More than 7,100 islands of the Philippines are surrounded by crystal clear bodies of water ${ }^{(2)}$. This makes the entire archipelago rich in marine resources. The Philippines has one of the world's biggest fishing industry ${ }^{(3)}$. However, human intervention causes destruction that many of these organisms are about to disappear. These resources have been abused to the point of exhaustion. The rapid rise of overpopulation, increased fish consumption significantly. Overfishing, dynamite and destructive fishing gears, as well as improper waste disposal and extreme weather, are the main factors for marine resources being in danger ${ }^{(4)}$. Lack of education informing the locals about the importance of our marine resources should be given value. This can help to protect and preserve our oceans.

The Visayas Sea is the most productive fishing ground with about 200,000 meters ${ }^{(5)}$. Because of different fishing pressures, the decline in fish productions becomes the problem in the area ${ }^{(6)}$. Around 7 municipalities are on the coast of the Visayan Sea with a total of 4,258 km. Also, there are 41 islands within 0-10 km, 8 with 10-15 km and 12 with $15 \mathrm{~km}$ from the shoreline ${ }^{(7)}$. Even Estancia is called the Alaska of the Philippines. One of the biggest fishing ports in Iloilo is located in Estancia and Carles.

Specifically, this study is based on the environment around the coastlines and the islands. Almost all learners have close encountered and experienced local marine biodiversity. Through dealings with their surroundings, these learners have already gained experiences and knowledge but many of them will not be able to transfer insights verbally. But this artistic side will help foster insights among teachers and students. The richness of marine biodiversity is a good source of instructional materials in teaching and learning elementary science. Recognizing the importance of the sea and eel grass in the program changed students' perception of marine habitats. This also changes their behavior such that they no longer throw waste into the sea ${ }^{(8)}$. The higher the grade level was, the more that students felt close to and were willing to care for the sea. Our study suggests that the program has helped to develop individuals who are knowledgeable about the fishing community of Hinase, fishermen's roles, and activities that would contribute to biodiversity conservation and were motivated to conserve Satoumi in the future.

Arts play a significant role in confirming to an engaging way to encourage active learning; thus, incorporating it in teaching can provide learners with quality school experiences ${ }^{(9)}$. Art and science are naturally connected. The core of art and science is always about discovery. Both artists work for pieces of art and scientists for a series of labs work. They prepared not only for systematic techniques but also for the creative way in knowledge and understanding of phenomena. Thus, in science learning in basic education, incorporating arts and science can help learners to think, discover, and relate ${ }^{(10)}$. Integrating visual aid into science helped scientific imagination and engagement for non-scientists ${ }^{(11)}$. There were many activities created using marine resources like transforming the classroom into a submarine by Ben Culverhouse at The Manor Church of England Primary School in Geography ${ }^{(12)}$. These allow learners to explain certain characteristics of organisms as well as use the topics in their Literature.

In the science curriculum, new concepts were introduced. These are the spiral approach and localization. A spiral progression is an approach of simple to complex ideas. The call for localization and contextualization can be a solution to this difficulty in the system $^{(13)}$. Also, to give solutions to these perennial problems, teachers must be creative and innovative. They are encouraged to make their teaching and learning more exciting and fascinating by the utilization of materials.

The result indicates that hands-on activity enriched instruction to be effective than traditional instruction. In the new science curriculum of the DepEd, a lot of hands-on activities were formulated ${ }^{(14)}$. Also, there was a significant difference between the means of the students' science achievement in favor of the experimental group using hands-on activities ${ }^{(15)}$. The results of this study are important especially for developing countries that cannot afford to use expensive science equipment to make the students physically active and engage in learning science. The use of recycling techniques and art materials are cheaper than high-end equipment and facilities. These materials are everywhere but all creative imagination can transform these materials into visual aids for hands on learning. Hence, this study was formulated.

This research was based on Laird's Sensory Learning by Dugan Laird. In 1985, he wrote the book 'Approaches to training and Development' and quoted that $75 \%$ of adult knowledge was obtained by visual aids or observation. Furthermore, using visual arts enhances students' learning ${ }^{(16)}$. The study was dedicated to utilizing arts through the form of 2 and 3 Dimensional artworks to enhance science teaching and learning. Because arts inspires learners to explore the concepts of scientific knowledge and skills, this works out to be a good combination that will help support the perennial problems in science education in the Philippines.

The multi-sensory education showed, it can lead to students' motivation and engagement, and also help teachers in various ways on learners' interest and performance ${ }^{(17)}$. This technique stimulates the development of student-centered classrooms because it allows students to be engaged productively. Another activity using movement revealed a positive result among students as well as teachers ${ }^{(18)}$. Also, creative teaching strategies to accommodate different learners in all levels from kindergarten 
to college are always commended as necessary but experts encourage educators to adopt more evidence-based methods to enhance effective instruction ${ }^{(19)}$.

The college physics students who took a hands-on approach activity on angular momentum and torque got better quiz performance. This learning process had activation in sensory and motor-related parts of the brain. For instance, study by Prof. Sian Belilock published online April 24 in Psychological Science, which comes from the Department of Psychology's Human Performance Lab, the findings stressed the importance of classroom practices that physically engage students in the learning process, especially for mathematics and science ${ }^{(20)}$.

Since this study was about using arts in science teaching, the article in 'Method in Science Teaching' published in Science Education in 1916 John Dewey influenced progressive methods in science education in America ${ }^{(21)}$. Also, Art as experiences connotes many aspects of learning science. John Dewey's Theories on art and art education will be applied in this research. Dewey believed that all of us are artists. Thus, arts converses with standards between good and evil and learning with transformative experiences. Dewey's view of the arts could improve the learning experiences ${ }^{(22)}$. Showing learners about creative outputs for learning science will stimulate curiosity and provide answers to their queries ${ }^{(23)}$. It will be helpful most especially to below-average learners.

In the Philippines, the lack of facilities, and equipment in the science curriculum, resulted in teachers to become creative and innovative. Thus, this study is about STEM which stands for Science, Technology, Engineering and Mathematics plus Arts. "Arts is the queen of all sciences communicating knowledge to all generations of the world" - Leonardo Da Vinci ${ }^{(23)}$. STEM plays some crucial roles in human lives, everything nowadays is about science. Consequently, exposing our students to STEM allows them to acquire knowledge on STEM-related ideas, and develop interest and passion to engage in STEM fields (Engineering for Kids). Learning through STEM, students were observed to being application-oriented and do more hands-on activities. But above all, learning science is about finding principles not covering meaningless materials ${ }^{(23)}$. Arts, on the other hand, help students develop understanding of concepts at the fundamental level. There are ten characteristics students develop in learning arts such as creativity, improved academic performance, motor skills, confidence, visual learning, decision-making, perseverance, focus, collaboration, and accountability ${ }^{(24)}$. Therefore, for so many decades STEM incorporating Arts known as STEAM is the thrust in many countries to make science curriculum for all.

Getty educators with museum conservators, curators, and scientists and a teacher advisory group explore the treasures of Getty Museum between intersections of the visual arts with scientific disciplines. The curriculum supports student proficiency focusing on production and conservation for arts, and scientific skills of investigation and experimentation for science. Science teachers and the proponents share resources and expertise from the effective implementation of the program ${ }^{(25)}$.

Arts integration can eliminate educational achievement gaps for economically disadvantaged students. In other words, when teachers reinforce academic concepts with the arts, students learn more and score higher on standardized tests ${ }^{(26)}$. This was used in fifth-grade science tests to scores of students not enrolled in arts-integrated classrooms. Also, the percentage of students scoring 'proficient or above' on standardized tests was significantly higher at schools participating in the Whole Schools Initiative that had effectively implemented the WSI arts integration model.

\section{Objectives}

This study aims to create visual aids made of recycled or waste materials on various marine resources such as mangroves, fishes, corals, and sea grasses found in the Visayan Sea in teaching science for K 12 Basic Education Program in the Philippines.

\section{Methodology}

\subsection{Informants}

How's the profile of the experts. These experts are science enthusiasts served as evaluators of the finished output. These experts were science teachers coming from big public schools in Northern Iloilo, and Faculty of Northern Iloilo Polytechnic State College who are experts in their fields and have a broad knowledge of their subjects and detailed knowledge of their specialty.

Purposive sampling was utilized in this study. Purposive sampling, a non-probability sampling method is also known as judgment, selective or subjective sampling. This sampling technique in which the researcher relies on his or her judgment in selecting participants in the study. Researchers often believe that they can obtain a representative sample by using a sound judgment ${ }^{(27)}$. The researchers employed this type of sampling technique because of prior knowledge about the qualification and standard of the science experts in terms of scientific pedagogy. 
Table 1. Profile of respondents as Science Experts

\begin{tabular}{|c|c|c|}
\hline Grade Level & No. of Experts & Qualifications \\
\hline 3 & 2 & Science Teachers \\
\hline 4 & 2 & Science Teacher, Master Teacher \\
\hline 5 & 2 & Science Teacher, With Innovation in Science Teaching \\
\hline 6 & 2 & Head Teacher, With Masters in Science, With Action Research Outputs \\
\hline 7 & 2 & $\begin{array}{l}\text { Science Teacher for almost } 10 \text { years, Engage in Research Completed Masters in Science } \\
\text { Education }\end{array}$ \\
\hline 8 & 2 & $\begin{array}{l}\text { Teacher in Science, Have creative output, Attended training in Localization and Contextual- } \\
\text { ization }\end{array}$ \\
\hline 9 & 2 & $\begin{array}{l}\text { Teacher in Science, Have creative output, Attended training in Localization and Contextual- } \\
\text { ization, One of the trainers in K } 12\end{array}$ \\
\hline 10 & 2 & $\begin{array}{l}\text { Teacher in Science, Attended training in Localization and Contextualization, Presented } \\
\text { paper in conferences }\end{array}$ \\
\hline 11 & 1 & $\begin{array}{l}\text { Master Teacher II, With units in Ph.D., Attended training in Localization and Contextual- } \\
\text { ization, Presented paper in conferences }\end{array}$ \\
\hline 12 & 1 & Teacher in Science, With Masters, Wanted to do Action Research \\
\hline College & 3 & $\begin{array}{l}\text { Science Experts, Conducted studies on science education, Created Instructional Materials, } \\
\text { Speaker training in Localization and Contextualization, Presented paper in conferences }\end{array}$ \\
\hline Total & 21 & \\
\hline
\end{tabular}

\subsection{Instruments}

How's the checklist on how to evaluate the outputs. The evaluators were given an evaluation checklist to assess the finish outputs. The finished products were assessed on the following; Tools and Materials (TM), Creativity and Originality (CO), Craftsmanship and Quality of Work (CQ), Organizations $(\mathrm{O})$. Tools and materials were about resources found within the locality with spending reasonable amount of money. Creativity and originality in this study meant that the artwork explored several choices to generate unique concepts, and unusual combinations of several ideas to connect with the science curriculum. While, craftsmanship was the artwork that was beautiful and patiently done, and the quality of work was as good as hard work could make it. The quality of work refers to comparing the actual features and the finished products of the 4 marine resources identified in this study. The organization is about the order of ideas on the researchers on how the 2 and 3-dimensional artworks were planned and created.

It was also evaluated for the possible incorporation in the K 12 Basic Education Program-Science Curriculum. The criteria for evaluation were Adapt to Use (AU), Create Instructional Materials before the Implementation (CIMI), Need Major Revision (NMR), and Poor Quality as Visual Aid (PQVA) if these outputs can be used as materials in teaching Science in basic education.

Table 2. Evaluation Formfor the creative outputs

\begin{tabular}{|c|c|c|c|c|c|c|c|c|}
\hline \multirow{2}{*}{ Output } & \multicolumn{4}{|c|}{ Finished Product } & \multicolumn{4}{|c|}{ For Instructional Materials } \\
\hline & TM & $\mathrm{CO}$ & CQ & $\mathrm{O}$ & $\mathrm{AU}$ & CIMI & NMR & PQVA \\
\hline \multicolumn{9}{|l|}{ Mangrove } \\
\hline \multicolumn{9}{|l|}{ Fishes } \\
\hline \multicolumn{9}{|l|}{ Coral } \\
\hline Seagrasses & & & & & & & & \\
\hline
\end{tabular}

The experts checked the boxes based on their evaluation of the outputs. This was utilized in this study along with feedback from the experts on improving the output and more engaging. A rubric was adopted for the easy evaluation of the artworks.

The researchers identified various marine ecosystems in the Visayan Sea. Then, they determined marine organisms to be part of the innovations. The researchers invited experts to evaluate the outputs. They were given an evaluation form. They rigidly observed in detail and scrutinized individually the creative output. After, these experts were interviewed about comments and suggestions before the outputs were incorporated in Science Pedagogy in K 12 Basic Education.

The evaluation forms were tallied and totaled. The percentage was used to get the final results. While in the qualitative parts, the verbal analysis was utilized in this research with the help of prepared guide questions. An interview and focus group discussion were employed, and tape-recorded. A consent letter was distributed informing the participants that the conversation 
will be recorded to capture the exact answers. This method was used in this study to formulate an understanding of the responses of the experts and to make the innovations effective before transferring to an actual classroom setting. The responses of science teachers were recorded and analyzed. They were triangulated and coded.

The science textbooks used in grades 3 to 10 were also analyzed. This was done to identify lessons to integrated with these finished products.

\section{Results}

\section{1. Bountiful Marine Resources}

Figure 1 showed the finished product on mangrove. The activity was called Mangrovy Kind of Love. This artwork was made using paper, folder, wire, glue, tape, paintbrush, and paint. The tree was composed of different leaves, roots, branches, etc. of mangroves found in northern Iloilo.

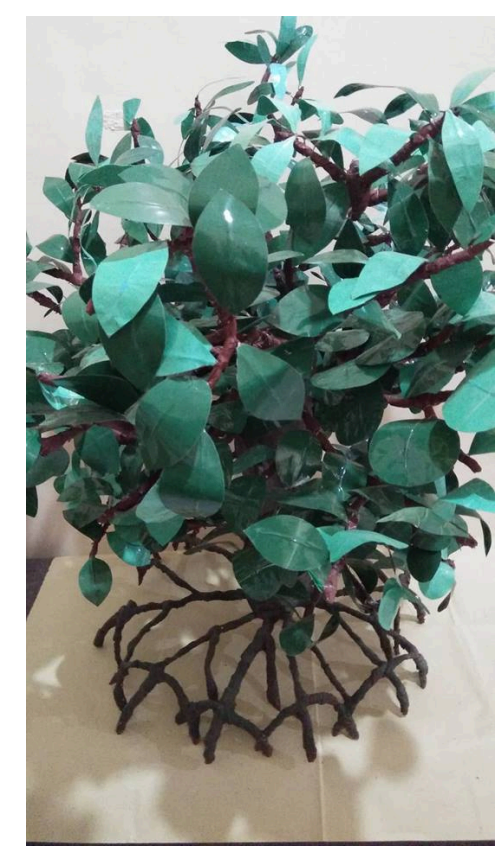

Fig 1. A 3-Dimensional Mangroves in $5^{\text {th }}$ District of Iloilo

Mangrove was selected in this study because almost 7 coastal municipalities have a mangrove ecosystem. Furthermore, Municipalities of Ajuy and Concepcion have century-old mangroves. This makes northern Iloilo unique among other municipalities and towns in the Philippines. Beside, Municipality of Concepcion informed school heads, from basic education to tertiary, to plant mangrove before allowing students to graduate. There is a mangrove park in Carles and Ajuy sponsored by private organizations both national and international.

There were almost 70 species of mangroves belonging to 20 families in the world and around 60 in the Philippines and 32 in Panay ${ }^{(28)}$. Mangrove is one of the most abundant marine resources in Northern Iloilo. Mangroves can help us during a natural calamity like a tsunami. Also, the mangrove ecosystem is a source for breeding sites for marine resources. Mangrove forests provide a wide array of ecosystem services but are one of the most severely threatened and undervalued ecosystems on Earth ${ }^{(29)}$. Thus, this salt-tolerant tree plays a crucial role in ecological integrity and services ${ }^{(30)}$.

This innovation can be used as a motivational activity. Learners will have a little background of true mangrove before going to the actual mangrove system. This can be used in lessons about knowing the different parts of the trees. Also, this can be employed in an enriching activity like making parts of the trees.

The next output was Fish in a Bowl, the materials used in this artwork were folders, glue, crayons, watercolors and colored pencils. Figure 2 is the illustration of fishes. These are fishes commonly found in the areas.

Estancia is called as the "Alaska of the Philippines". The bountiful fishes in the area provide food and give livelihood opportunities to everyone. However, various human activities such as dynamite fishing cause many species to vanish. It is important 

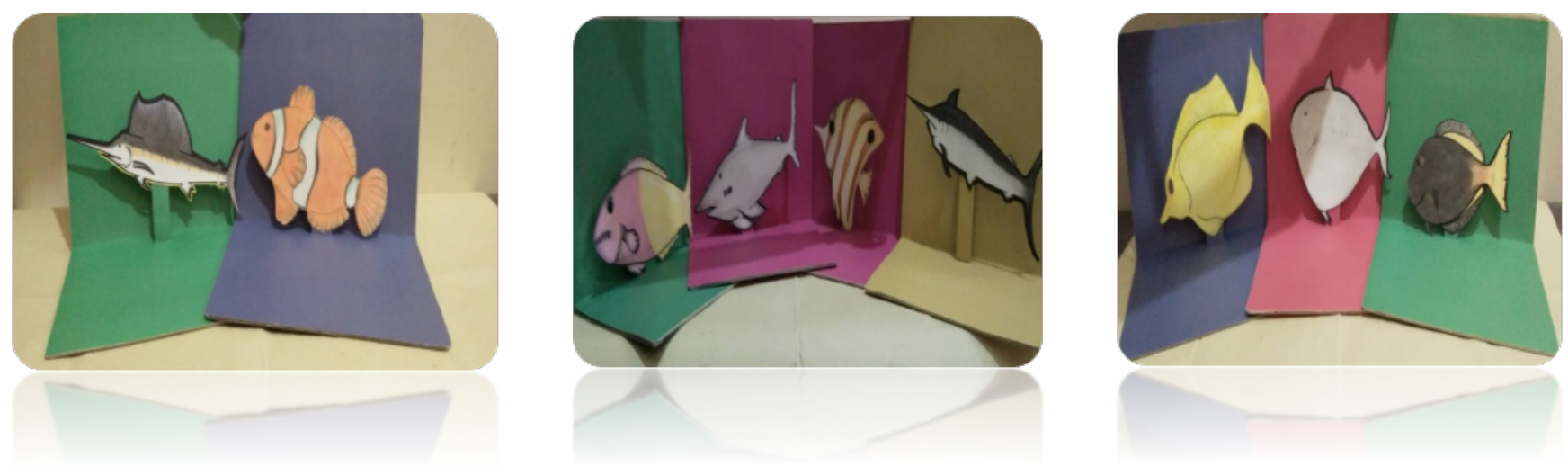

Fig 2. 2 Dimensional Fishes Found in Northern Iloilo

to educate our young minds to protect and preserve our natural resources. This will be used as motivation activity, lesson proper or even enrichment and in quizzes on parts and functions of the animals.

There were managed and unmanaged coral ecosystems in the $5^{\text {th }}$ District of Iloilo. Northern Iloilo has beautiful corals within the vicinity. The activity will be used during enrichment; the outputs of the students will be donated to other elementary schools for instructional materials.

The Philippines is historically had the world's most amazing coral reefs. There is probably nowhere in the world with stronger human pressure on corals and associated marine resources. 99 percent of the area's coral reefs were destroyed by illegal practices like dynamite fishing. Thus, the Department of Environment and Natural Resources focuses on restoring and rehabilitating our coral reefs ${ }^{(31)}$. But if we could integrate into our curriculum, and educate the young children about the situations of our rich and diverse coral reefs, it will help them become warriors and guardians of our ocean. Awareness among the young generation is the solution for the biggest problems of our country in terms of marine resources.

Figure 3 showing the different corals found in Northern Iloilo. The creative output is called 'CORAL: Bleaching No More'. The materials used were old newspapers, glue, brush, and paints.
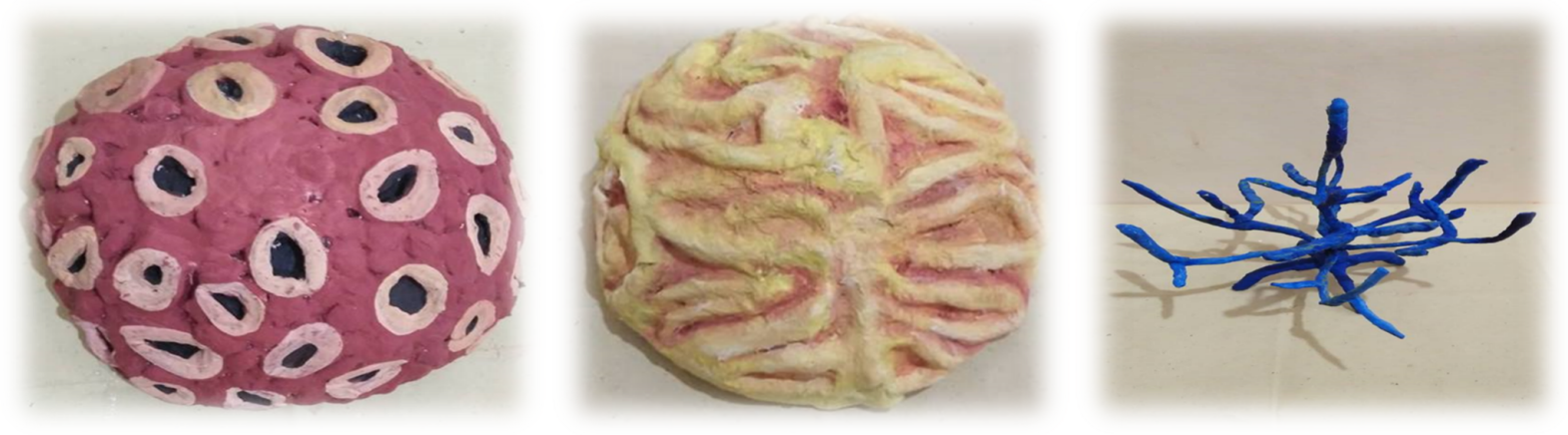

Fig 3. The 3 Dimensional Illustration of Coral

Figure 4 is the illustration of sea grasses. This last output was entitled "Grasses on the Sea." The materials used are folder, crayons, watercolor, glue, scissor and pentel pen. There were around 7 sea grasses species in islands of Municipality of Carles and some other coastal areas in other municipalities in northern Iloilo. Similar to the fishes, sea grasses were 2 Dimensional 
artworks that can be used for identifying parts and functions of the photosynthetic organism inhabiting our oceans. This can also be used in the ecosystem as well as during the discussion of photosynthesis. These visual aids could be used to highlight the facts like plants that need light are not only found in the land but also the water and these plants provide food for fishes, other animals, and shelter for small fishes.
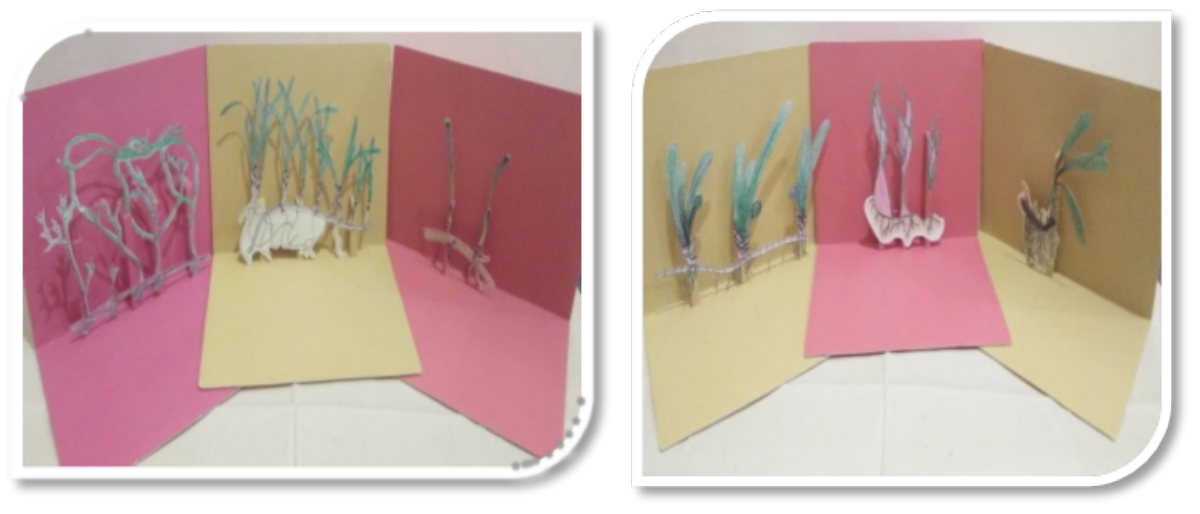

Fig 4. Two Dimensional Illustration of Seagrasses

Seagrasses have around 50 species under 2 families and 13 genera. Family Potamogetonaceae consists of 10 genera and 39 species. While Family Hydrochanitaceae consists of 3 genera and 11 species. In the Philippines, 16 taxa were identified ${ }^{(32)}$. But because of human intervention and recent natural calamities, they are about to vanish. To save these plants, we must start with our students. We must campaign for the preservation and protection of this species. We must encourage our educators to incorporate into the science curriculum.

The missing component in STEM is Arts; this makes it STEAM. Enumeration of activities, where STEM and Arts go handin-hand such as art and science, have long existed and developed collaboratively in the work of legendary Leonardo Da Vinci and the renowned Chinese polymath Su Song. Also, Carl Jung was the artist-scientist, these pioneers were builders, inventors, and dreamers. Furthermore, camouflage for soldiers was invented by American painter Abbot Thayer, Earl Bakken based his pacemaker on a musical metronome, Japanese origami inspired medical stents and improvements to vehicle airbag technology, and Steve Jobs described himself and his colleagues at Apple as artists. At TED 2002, Mae Jemison stated science and the arts is not that they are different sides of the same coin. In 2008, the DANA Arts and Cognition Consortium supported brain research, reported that arts affect other areas of learning. While in John Hopkins Learning, Arts, and the Brain Summit in 2009, it was stated that Art and music require the use of both schematic and procedural knowledge. Also, MIT researcher Jie Qui combined physical dance with subjects like math and geometry. This showed that amalgamation of Science and Arts are new trends nowadays ${ }^{(33)}$.

Furthermore, one of the approaches in the conceptual framework in the science curriculum of the K12 Basic Education Program is multi/interdisciplinary.

\subsection{Evaluating the Creative Outputs}

Summarizes the evaluation results of the science experts on the four creative outputs.

The highest assessment of science experts about the creative output was the "Mangrovy Kind of Love", followed by "Coral: Bleaching No More," "Fish in a Bowl", and lastly "Grasses of the Sea". The creativity and originality for mangrove and corals got perfect score because science experts believe that this artwork is new to the especially is about local marine resources, and made of waste materials. The tool and materials are easy to find, and the work is very interesting especially in coral. While the Organization got the lowest evaluations because the description was not part of the artwork which many of them believe that it is very important.

In terms of adopting the materials for science teaching, the results showed that they wanted to use the output but lesson plans or instructional materials must be created. The fishes can be good strategies during lesson proper. The coral is also a good activity to show to the students the actual corals since they were little coral reef left in Iloilo. The process of how these innovations will be incorporated in science lessons. 
Table 3. Results of the Evaluation of the Science Experts

\begin{tabular}{llllllllll}
\hline \multirow{2}{*}{ Output } & \multicolumn{3}{l}{ Finished Product } & \multicolumn{6}{c}{$\begin{array}{l}\text { For Instructional Materi- } \\
\text { als }\end{array}$} \\
\cline { 2 - 10 } & TM & CO & CQ & O & T & AU & CIMI & NMR & PQVA \\
\hline Mangrove & 90 & 100 & 95 & 86 & 93 & 71 & 95 & 48 & 10 \\
Fishes & 95 & 71 & 90 & 57 & 78 & 71 & 95 & 90 & 10 \\
Coral & 100 & 100 & 95 & 86 & 87 & 90 & 95 & 48 & 14 \\
Seagrasses & 90 & 67 & 86 & 62 & 76 & 52 & 95 & 95 & 81 \\
\hline Abbreviations: TM; tools and materials, CO; creativity and originality, CQ; craftsmanship and \\
quality of work, O; organizations, AU; adopt to use, CIMI; create instructional materials before \\
the implementation, NMR; need major revision, PQVA; poor quality as visual aid
\end{tabular}

\subsection{Enhancing the Creative Output}

Summarizes the responses of the experts on how to make the innovations more effective in the classroom.

Table 4. The response of the Experts on the Innovations

\begin{tabular}{ll}
\hline Resources & Enhancement \\
& 'The leaves are almost the same, please refer to different textbooks, flyers as well as websites showing \\
the actual type of leaves of mangrove.' & 'See the actual color of the leaves. Mangrove has different colors.' \\
'There is no flower and fruits. It's better to show it too.' \\
'There was a different type of flowers and fruits.' \\
'The roots are almost the same. Mangrove has a different type of root for oxygen.' \\
'See to it, that all the fishes found in the Visayan Sea will be a showcase in the innovations.' \\
'Kindly visit the Bureau of Fisheries and Aquatic Resources in Iloilo City and discuss the output.' \\
'The fishes must have their local and English as well as scientific names.' \\
'The color is pale. Make it a little brighter, learners is interesting to learn if colors are interesting.' \\
'The seagrasses are so small.' \\
'It is also good to have the local and English name. Scientific names are also good.' \\
'The illustration was small. A bigger one is better.' \\
Seagrasses
\end{tabular}

The $21^{\text {st }}$-century science classroom focuses on critical thinking skills, problem-solving, research, inquiry, and collaboration. A part of the focus includes development of creative mind and artistic spirit in a child ${ }^{(34)}$. Even in the new age of technology, the arts play a significant part in science. The hands-on activities with art concepts are always meaningful and inexpensive for teachers. In the Philippines, many teachers are complained that they are using their own money for instructional materials. Both groups who took the arts-integrated class in astronomy and life science, and environmental science and chemistry performed better in this class ${ }^{(35)}$. Thus, this study is a hope to help learners appreciate science, and increase interest, and for teachers to make science pedagogy more fun and enjoyable.

4.4. Marine Resources in Science Curriculum

Summarizes the topics of the marine resources found in various grade levels. The results showed that marine science is one of the main thrusts of the Filipino basic science curriculum. One of the major improvements in the science curriculum is about encouraging learners to become a responsible steward of nature. It is about educating our students about Philippine's biodiversity, this will further make students to prevent rapid deterioration of natural resources in Philippines.

The topics are all general, focused on living things and their environment; thus teachers can incorporate local marine resources in the subject. For example, in grades 3, 4, and 6 fishes and sea grasses can be used in the topic animals and plants, and mangrove and corals in the ecosystem. In grade 4 the topics are about plants and animals that can adapt to water, grade 5 is about reproduction, and grade 6 is about vertebrates and invertebrates, and flowering plants. Therefore, it is clear that all the artworks made in this study have the potential for instructional materials in the science curriculum. In junior high school, Unit 1: Diversity of Materials in the Environment in Module 3 'Living things other than Plant and Animals' as well as in Module 4 'Reproduction: The Continuity of Life' for grade $7^{(36)}$. Also, in grade 8 Unit 4: Living Things and Their Environment, Module 1: Biodiversity in the topic the Animal Kingdom specifically in fishes ${ }^{(37)}$. While in grade 10 in Module 4 : Ecosystem: 
Table 5. Marine Resources in Basic Science Curriculum

\begin{tabular}{ll}
\hline Grade Level & Topics \\
\hline 4 & Animals and Plants Adapt in Water \\
5 & Intertidal Zone, Estuaries \\
6 & Mangrove Swamp, Coral Reef \\
8 & Sponges, Cnidarians, Mollusks, Echinoderm, Arthropods Fishes, Amphibian, Reptiles, Mammal \\
9 & Water Pollution, Destruction of Coastal Resources \\
10 & Value of Biodiversity, Environmental Issues \\
\hline
\end{tabular}

Biodiversity ${ }^{(38)}$. Thus, this artwork can be utilized as visual aids in teaching the subject.

The concept of localization and contextualization that the national government wanted teachers to concentrate on is the objective of this study. The entire archipelago composed of different flora and fauna that can be possible resources for instructional materials but very few are interested. Thus, the results will be the basis for basic science educators to increase their knowledge of the use of materials in the context of local resources.

All four major organisms like mangroves, fishes, corals, and sea grasses are part of the science curriculum in basic education. This has potential as tools in enhancing the interest of learners in science and curriculum guide focused on general environmental education. The innovations especially using recycled materials is not a new idea for DepEd teachers. But focusing on local marine resources integrated into science teaching and learning is new concept since the objective and contents are general. Incorporating arts in the science curriculum is always interesting to below-average learners. Also, this is to eradicate notions about science learning, hence educators must be innovative. This will help teachers to increase the performance of students in various forms of assessment and evaluation. Almost all science teachers wanted to adopt the innovation; since DepEd are encouraging teachers to create materials in the context of local resources. DepEd has planned to provide instructional materials such as textbooks, teachers' manuals, and curriculum but it is still limited. Based on the suggestion of experts, the creative outputs must be enhanced. Experts from the field of visual arts must be part of the evaluating team. Also, the products must be assessed by professionals from the Bureau of Fisheries and Aquatic Resources as well as the College of Fisheries from the University of the Philippines-Visayas, Iloilo of School of Fisheries and Nothern Iloilo Polytechnic State College, and Southeast Asian Fisheries Development Center.

\section{Conclusions}

All four major organisms like mangroves, fishes, corals, and sea grasses are part of the science curriculum in basic education. These organisms are abundantly found in various ecosystems in the Visayan Sea. The results showed 4 major local marine resources found in the diverse marine ecosystem in the Visayan Sea. The outputs are called 'Mangrovy Kind of Love,' 'Fish Bowl', 'Corals: Bleaching No More', and 'Grasses on the Sea'. Most of the materials used were old newspapers, and colored folders, glue, wire, and coloring and art materials. The materials used are easy to find; they can be found inside the classroom. The majority of the science experts gave positive feedbacks but with few negative comments on making the artworks more attractive to the interest of the learners, as well as making instructional materials.

The highest assessment of science experts about the creative output was the 'Mangrovy Kind of Love', followed by 'Coral: Bleaching No More,' 'Fish in a Bowl', and lastly 'Grasses of the Sea. The creativity and originality for mangrove and corals got perfect score because science experts believe that this artwork is new, especially a visual aid involving local marine resources and made of waste materials. The tools and materials are easy to find, and the work is very interesting especially on corals. While the Organization got the lowest evaluations because the description was not part of the artwork which many of them believe that it is very important.

In terms of adopting the materials for science teaching, the results showed that they wanted to use the output but lesson plans or instructional materials must be created. The fishes can be good strategies during lesson proper. The coral is also a good activity to show to the students the actual corals since there are little coral reef left in Iloilo.

The comments and suggestions given are very helpful. These innovations can be incorporated in grade 4 on animals and plants, adaption to water, grade 5 estuaries, and the inter tidal zone, and 6 mangrove swamp and coral reef, and grade 8 about fishes. However, there were topics in other grade levels where in these outputs can be used as motivational or enrichment activities. This study recommended creating instructional material, and research to evaluate the effectiveness of artworks. Upon the incorporation of the suggestions and comments of the experts, the innovations must be tested. Further study is recommended; action research must be conducted. This is to distinguish the effectiveness of the creative output. The scarcity of science materials 
will be solved by integrating arts in teaching the basic science curriculum in the Philippines.

\section{Acknowledgment}

This work was supported in part by JSPS KAKENHI Grant Number 19F19014. Also, we would like to extend our heartfelt gratitude to all science teachers in Northern Iloilo, the Philippines who participated and supported this endeavor. Grateful mention to Dr. Ma. Theresa G. Palmares, president of NIPSC for the encouragement and motivation to pursue this study. Gratitude to the Office of Research and Development Services - NIPSC, for the financial assistance provided for the instructional materials. A special acknowledgment to Dr. Harold O. Buenvenida, faculty of Capiz State University for all the comments and suggestions in this study.

\section{References}

1) Ocean for all. . Available from: https://moteoceansforall.org/wp-content/uploads/2018/02/OceansForAll_MoteCaseForSupport_ffw.pdf.

2) Ayala J, Bautista P, Pajaro M, Raquino M, Watts P. Sustainable development of Philippine coastal resources: Subsidiarity in ethnoecology through inclusive participatory education. International Review of Education. 2016; 62(2):161-185. doi:10.1007/s11159-016-9546-9.

3) Your fish is your future. . Available from: https://news.mb.com.ph/2019/06/05/your-fish-is-your-future/.

4) Fish depletion, marine habitats destruction in the Philippines. . Available from: https://www.gaiadiscovery.com/marine-life-latest/fish-depletion-marinehabitats-destruction-in-the-philippine.html.

5) Bfar. Commercially fishery stock assessment of the Visayan Sea in the Region VI for the year. Iloilo City, Philippines. 1998. Available from: http: //www.reefbase.org/resource_center/publication/pub_24636.aspx.

6) Hermes R, Armada NB, Aparri RA, Zarragoza EC, Lohmeyer U. Overexploitation in the Visayan: Designing a project solution. In: Turbulent Seas: The Status of the Philippines Marine Fisheries. Springer. 2004 p. 287-309.

7) Ferrer A. 2016. Available from: http://dlc.dlib.indiana.edu/dlc/bitstream/handle/10535/7281/1239.pdf?sequence=1\&isAllowed=y.

8) Sakurai R, Uchera T, Yoshioka T. Students' perceptions of a marine education program at a junior high school in Japan with a specific focus on Satoumi. Journal of Environmental Education Research. 2008; 25(2):222-237.

9) Upitis R. 2011. Available from: http://www.edu.gov.on.ca/eng/literacynumeracy/inspire/research/WW_Engaging_Arts.pdf.

10) Discovering science through art-based activities. . Available from: https://beyondpenguins.ehe.osu.edu/issue/earths-changing-surface/discoveringscience-through-art-based-activities.

11) Gurnon D, Voss-Andreae J, Stanley J. Integrating Art and Science in Undergraduate Education. PLoS Biology. 2013; 11(2):e1001491-e1001491. doi:10.1371/journal.pbio.1001491.

12) Three creative ways teachers can explore oceans in the classroom. . Available from: https://www.theguardian.com/teacher-network/2015/may/20/exploreoceans-classroom-three-creative-ways-teachers.

13) Dep ED, To. Science Curriculum Guide Pasig City. 2013; p. 12-12.

14) Sadi O, Cakiroglu J. Effects of hands-on activity enriched instruction on students' achievement and attitude towards science. Journal of Baltic Science. 2011; 10(2):87-97.

15) Hussain M, Akthar M. Impact of hands-on activities on students' achievement in science: An experimental evidence from Pakistan. Middle-East Journal of Scientific Research. 2013; 16(5).

16) .. Available from: https://teacherofsci.com/learning-theories-in-education/.

17) Stoffers M; Using a multi-sensory teaching approach to impart learning and community in the second-grade classroom. 2011. Available from: https: $/ /$ rdw.rowan.edu/cgi/viewcontent.cgi?article $=1109 \&$ context=etd.

18) Anderson J; The Impact of Sensory-Based Movement Activities on Students in General Education. University of Puget Sound. 2016. Available from: https://soundideas.pugetsound.edu/cgi/viewcontent.cgi?article=1001\&context=drot_theses.

19) Arbuthnolt KD, Kratzig GP. Effective Teaching: Sensory learning styles versus general memory process. Innovative Teaching. 2014; 4(2).

20) .2019-02-12. Available from: https://news.uchicago.edu/story/learning-doing-helps-students-perform-better-science.

21) Wong P, Pugh K. The Dewey Ideas Group at Michigan State University. Learning Science: A Deweyan perspective. Journal of Research in Science Teaching. 2001; 38(2):317-336.

22) Goldblatt P. How John Dewey's Theories Underpin Art and Art Education. Education and Culture. The Journal of the John Dewey Society. $2006 ; 22(1): 17-34$.

23) .. Available from: sierraschoolworks.com/section/wp-content/uploads/2013/11/Exploring-STEAM-Science-Technology-Engineering-Arts-Math-EDayton-Sierra-College-STEM.pdf.

24) . 2019-02-12. Available from: https://www.learningliftoff.com/10-reasons-arts-in-education-important-kids/.

25) .2019. Available from: http://www.getty.edu/education/teachers/classroom_resources/curricula/art_science2/index.html.

26) Effective arts integration improves test scores. 2019. Available from: https://www.sciencedaily.com/releases/2013/10/131022170624.htm.

27) Black K. Business Statistics: Contemporary decision making" 6th edition. New Jersey, USA. John Wiley \& Sons. 2010. Available from: https://books. google.co.in/books/about/Business_Statistics.html?id=wt6fuAAACAAJ\&redir_esc=y.

28) Primavera JH, Sadaba, Rs, Lebato, Mjhl A, P J. 2004. Available from: https://repository.seafdec.org.ph/handle/10862/3053.

29) . 2004. Available from: https://www.mangrovesforthefuture.org/news-and-media/news/asia-region/2014/world-parks-congress-called-to-protectrestore-amd-expand-mangroves/.

30) Cudiamat MA, Rodriguez RA. Abundance, structure, and diversity of mangroves in a community-managed forest in Catalagan. Asia Pacific Journal of Multidisciplinary Research. 2017; 3(5):27-38.

31) .2019. Available from: https://savethephilippinecoralreefs.wordpress.com/2012/08/05/visayas-marine-life-deteriorating-according-to-the-denr/.

32) Fortes MD. The state of seagrass ecosystem and resources in the Philippines. Transaction of the National Academy of Science and Technology: USA. 2013; p. 57-89.

33) Pomeroy ST. From STEM to STEAM: Science and arts go hand-in-hand. Scientific American, Division of Nature America. 
34) . 2019. Available from: https://www.scholastic.com/teachers/blog-posts/meghan-everette/art-integration-easy-ideas-combining-science-and-art/.

35) .. Available from: https://www.marthastewart.com/1537187/arts-help-students-succeed-science-new-study.

36) Barbosa MB, Guirro EC, Nunes FR. Evaluation of sensitivity, motor and pain thresholds across the menstrual cycle through medium-frequency transcutaneous electrical nerve stimulation. Clinics. 2013; 68(7):901-908. doi:10.6061/clinics/2013(07)03.

37) Alvarez LA, Dg A, Apurada, Hl, Carmona, Mpp, et al. TB. Science Learner's Module (Grade 8). Studio Graphics Corp: Pasig City: Philippines. 2014; p. $1-337$.

38) Acosta HD, Alvarez LA, Dg A, Arre, Rd, Carmona MR, et al. Science Learner's Materials. 2015; (10):1-475. 